\title{
Market Regulation and Marketing of Enterprises as a Factor for the Development of SMEs in Kosovo
}

\author{
Fatos Ukaj \\ Associate Professor, Economic Faculty, \\ University "Hasan Prishtina", Prishtinë, Kosovo \\ Husnija Bibuljica \\ Associate Professor, Faculty of Business, \\ University "Haxhi Zeka", Pejë, Kosovo \\ Corresponding Author
}

Doi: 10.2478/ajis-2019-0004

\begin{abstract}
Based on observation, enterprises are an economic organization established to make a profit. On the other hand, marketers are responsible for ensuring customer's satisfaction. This is done firstly by increasing the growth of sales which will bring good business results. To reconcile these two approaches, we have to distinguish what entrepreneurs that run SMEs do. The environment has a significant influence on the development of SMEs. Furthermore, we consider the Legal issues and Legislation as the main factor that will let SMEs satisfy customer needs and generate profits. Also, we conducted field research where we used survey questionnaire as an instrument for data collection. Based on the findings of this study, we drew out conclusions and recommendations that will be useful for the future treatment of SMEs, and as a real force of the economic development of a country. All this, therefore, should be based on marketing concept requirements and appropriate legislation as support and insurance for investments made.
\end{abstract}

Keywords: SMEs, marketing, regulation, competition, management

\section{Introduction}

In the European economy worldwide, SMEs have played and still play an important role in the economic development of their countries. In Kosovo, these enterprises have been treated with insufficient attention which was not comprehensive. As a result, that is the reason for not achieving the same or similar results in the business of these enterprises, when compared with achievements of SMEs of other countries in the region and beyond. We have considered the advantages and opportunities of the SMEs, relying on existing regulation, and implementation of the marketing concept as the initiator of their ongoing expansion and development in business. Seen as a factor for Kosovo's economic development, these are some of the issues that will be analyzed. Also, conclusions about the opportunities and advantages of these companies during their development will be drawn, and the challenges that await them in business will also be considered. The marketing concept is suitable for application in SME as a factor in their "step by step" development.

Nevertheless, it is also used in preparation for the expansion of their business activities when they can discover strategic partners or powerful investors. Any review of the enterprise position in the market begins with an analysis of the actual company position in the market, and strategy 
development for re-positioning the new circumstances created because of the entry of new firms in the market (Veseli, 2009). If the company identifies and is aware of the problems and barriers, then it has to clarify its position and power in the competition by finding the answer in concrete question: "What to do to get there" (Porter, 2008). It was noticed that in the life cycle of successful enterprises, there comes a time for expansion and innovations. During the last decade, the importance of the internet has increased significantly, becoming more than an important business opportunity. It has become an indispensable technology being applied in daily business (Ukaj, 2018). This necessarily requires investment in financial, technological, human resources, and an increase in management capabilities. Therefore, to achieve the objective of the paper, reliable sources and the proven methods are used as field and desk research. Field research has been carried out in person, continuing with processing data obtained, making evaluation and examination to reach reasonable conclusions about issues raised. Observation combined with interviews and structured questioner has been selected as a method for data collection. The analyses of findings presented below are expressed as a percentage for each question and issue raised. The paper is structured in few parts starting from general observations and definition of the problem, approach to theoretical achievements, and analyses of SMEs in Kosovo, up to the conclusions on the issue.

\section{Development of SMEs: Difficulties for Expansion}

The role of SMEs in the majority of the cases in the vocabulary of politicians and economic experts is found as irreplaceable as far as the future of economic growth is concerned. Consequently, the issue to be raised is on how such SMEs were developed so far without the safeguarding and assistance from the government. The main goal of this paper is to address the issues that are related to the professional-managerial process as an opportunity for SMEs growth in Kosovo. Marketing, with the legal framework, informal economy, time to time restrictions on gaining access to foreign markets, infrastructure, and electrical energy are a wide number of issues that have to be addressed and solved one after the other. Also, there is an unlimited number of definitions about SMEs and economic growth, but the line where the distinction is between SMEs and LEs (Large Enterprises) is the number of the employees (Dawing \& Brown, 1992). Policies and development programs for SMEs in Kosovo were compiled in compliance with the recommendations of the European Charter for Small Enterprises in 2003 when Kosovo became a member of this Charter. The Agency for Support of SMEs is also a national coordinator of the European Charter for Small Enterprises in Kosovo. In 2016, in Kosovo, there were 10,316 Microenterprises, 100 Small enterprises, and 6 Medium enterprises registered (KAS, 2017).

\section{Marketing as a Factor for Growth of Enterprise}

The use and practice of international experiences and possible international support in increasing the capacity of SMEs - should be achieved by cooperating with Enterprises, Groups of interest (commercial chambers), and governmental institutions to find and attract possible international assistance which is based on priority needs of SME sector. Of course, previous experience should be a lesson that more can be achieved in this direction. To have the right view on the marketing concept, we have to list activities that comprise the term "Marketing." Thus, they are marketing environment, marketing research, consumer behavior, product policy, price policy, distribution and place, promotion policy, marketing planning, and marketing organization.

It is obvious to entrepreneurs that even when they start thinking and considering business ideas, they are already involved in marketing activities known as market research. The question is whether they are aware of the steps they are taking which are described in the explanations of the marketing concept. Everything listed above and more of that is to be considered and analyzed by entrepreneurs at the start of realization of their business ideas. One of the questions the management of SMEs has to face frequently is: "what are the changes and expectations on the market?" In most cases, changes are to be considered, and there can be changes regarding legislation and environment, on demand and purchase force, technological innovations in the market, social aspects and political changes, changes in world economy, etc. (Gamble \& 
Thompson, 2010; Barney, 1991). When we analyze the organizational structure of the SMEs, we noticed that the marketing department does not exist in $76 \%$ of the cases. Hence, activities such as market research, sales promotion, and management of customers are performed by their department manager.

In most cases, the sales manager is responsible for running the "marketing" activities. Director of Enterprise or Sales Managers is responsible for the growth and development of product groups/services. Since each of them has many products (in case of retail), inevitably, some products or customer groups are neglected unfairly. Therefore, this would help all groups to achieve the planned growth or at least come closer to the planned objectives. The fact that they are private property makes them more flexible and adaptable to fulfill the market demand, and which refers to the owner's entrepreneur skills (Ukaj, 2010b). It is necessary to create new work positions and increase the number of employees to deal with specific groups of customers or introduce key account management. It is unnecessary nowadays to centralize the marketing activity to an individual or even a department. Thus, all the company's personnel should be directed to the market. This means that the management style should always be oriented towards the market for the purpose of planning, organizing, and implementing the marketing strategies that bring benefits to the company. The company's market can be local, national, or international. This must be clear to the management because it is impossible to act in the same manner in all the markets, considering that companies are different, and they have their specifics. Considering the small number of employees in companies and the capacities of SMEs, the managers that want to apply the marketing must create their style of managing which is characterized by: customer oriented, future activities planning, construction of a system, and the use of specific business methods. In the case when the company aims to be market-oriented, and achieve consumer satisfaction, it must take into consideration that the target groups are becoming smaller. Thus, this shows that quality must be the objective of the company through increasing maximum consumer's service. Considering this, we are conscious that in most of the cases, the owners as managers try through their intuition to take all the decisions. In most of these cases, they do not clearly define the companies or employees' objectives, they have no training for the employees, and the management process is made by the owner or his chosen person who, in most cases, is promoted by an employee that is good and well-qualified. In the case of SMEs, this causes damages to the company because the company loses a specialized-employee, which results to having a bad manager. In the case of SMEs in Kosovo, $70 \%$ of the actual managers were recruited from the company itself, and the job advertisement chose only $21 \%$ of them. $9 \%$ of cases were chosen in other manners, for example, the attraction of the successful manager by other company. In general, it is important to highlight that most of the managers of SMEs are about 30-45 years old. Thus, according to gender representation, only $15 \%$ of women are managers in the SMEs in Kosovo. It has been observed that the relation owner-employee has special importance, and the owner and employee must have the confidence to see the employee as energetic, careful, enthusiastic, etc. This brings us to the conclusion that the employee is under pressure to fulfill the owner's expectations, and the failure in any owner's expectation to the employee means dismissal. The planning is an assumption for successful marketing activities, as an active effort for the future, taking the right measures to adopt the plan according to the changes that occurred. In the majority of SMEs, $73 \%$ of cases do not have marketing plans, short-term or long- term. It is seen as approximate planning based on the past period. As a result, they do not have a detailed or continuous plan.

\subsection{Marketing Mix Elements:A Challenge to SMEs}

Companies' marketing strategies must be in harmony with their possibilities and capacities, and this as a whole cannot be realized if the employees of the company do not implement it. The marketing strategies implementation in SMEs is at different levels independently to which element of the marketing mix is given more importance. The most important part of a plan or activity of marketing in SMEs obviously must be the product respectively. The service based on the theory is identified through product policy followed by price policy, distribution policy, and promotion policy. The 
company must know and manage its product as a product/service that fulfills the consumer needs. By understanding consumer needs, the company must develop new products. In case of selection of new products, $53 \%$ of cases were done based on the attraction of brand for customers. In $36 \%$ of cases, the selection was done based on other circumstances (financial, logistic conditions, etc.). It was observed that the companies in the context of product policies are paying attention also to some other instruments of product policies such as packaging, service, warranties, marks, etc. This is realized through the units/departments that care for the management of the product, production, supplying, and sale activities. Usually, this activity is done by the Production Manager, and in other cases can be nominated as a Brand Manager or done differently.

Pricing policy in the companies is usually determined based on the position of the product in the market and expenses model of supplying plus the profit (Ukaj, $2010 \mathrm{a}$ ). There are cases when the company has a price determined by the producer, and that price has a percentage as an intermediation profit. Other methods are also used in price formation: track the competitors, the season, expiry date, etc. At $73 \%$, the entrepreneurs that sell products to the intermediaries, retail or wholesale, determine a unique price for all the market. This results in the escalation of the proportions that is given to the intermediates as a form of a rebate. In only $30 \%$ of the cases, "casa sconto" is used as a discount for immediate payment. In local companies, the price is not observed as an important element in the implementation of marketing activities.

The foreign companies that collaborate with Kosovo SMEs usually push them for the campaign with promotional price, as a support in the positioning of the market and in enhancing the image to the consumer. Distribution policy to the companies is concentrated in the other marketing activities. This is with the aim that the products or services get to the consumer and satisfies their needs. If the commitment of SMEs toward the consumers is in long-term, then these companies pay more attention so that the products or services get to the consumer on time, at the right place, and in the right quantity. The distribution policy in Kosovo determines, to a large extent, the image of the company, not only to the loyal consumers but also to the potential and possible consumers. In general, the penetration of distant consumer is the objective of the SMEs in $89 \%$ of the cases. This is without regard for the participation percentage of any region, or sale objectives in the general sales of the company. It was observed that companies are concentrated firstly towards the distribution as a process of offering the product closer to the consumer. Second, the companies use a logistic or physical distribution from the company to the intermediaries or directly to the consumer. It was noted that $65 \%$ of companies use intermediaries as a way of offering the product to the consumers. Thus, the other part does this by themselves or through the distribution network. Also, there are cases of both combinations. In the distribution policy of SMEs, it can be seen that they use different strategies of distribution from the intensive strategy. In $52 \%$ of cases, there is no classification of selling points, intermediaries, or things like this. Thus, this uses any manner to bring the product closer to the consumer.

Nevertheless, some companies use exclusive and selective strategy. In at least two cases, the approach in entering into a business of virtual distribution or sell through the internet (ecommerce) was noted. In general, the companies pay more attention to the distribution, and for this reason, in many cases. Supported by the selling power, companies try to achieve competitive priorities exactly in this activity field in marketing, by the combination of other elements too. Every enterprise can find some key reasons why they should consider the possibility of introducing their online products or services if they have not done it so far. Or if they are already in this internet marketing activity, they should be convinced that the decision they have taken is more than a "good opportunity." Thus, it is their way of doing business. The use of the internet is proliferating even in Kosovo and other regions (Ukaj, 2018).

Promotion Policy: Entrepreneurs in SMEs are convinced that developing promotional activities, such as publicity and advertisement, refers to marketing development. Thus, it is limited to this in carrying out and implementing the concept of marketing. This is the reason for the lack of professional expertise in marketing or the limitation of financial resources in embarking on an inclusive marketing plan. It is appropriate that the management of SMEs should be conscious of the importance of communication with the consumers' (their buyers) through the promotion forms. In $72 \%$ of the cases, the enterprise spent money on any form of promotion during a business year. It 
was observed that communication in most cases is unilateral, without any returning information over the reaction of those who receive the message. In $68 \%$ of cases, this communication uses massive communication which is technical, and most of the publicities were done using mass media. The forms that are used for the promotion, even for products or services and for the company's promotion, are publicities. The publicity in $90 \%$ of cases is prepared and designed by the marketing agency, or by media with the intervention and suggestions of companies' manager. The publicity is used to inform the public about the charity actions of the company, donations, or innovations, for example, the opening of a new point of sales, etc. The most prevalent form of promotion is sales promotion as a combination of other activities of marketing. The sales promotion can be described as a marketing activity that aims to stimulate the purchases with the intermediation of company's agents that are interested to directly promote the product to the consumer, the product's profits, and priorities toward the other products. The progress of sales in this process relates the company's buyers, intermediaries, and product's consumer in a way to grow the sales and circulation of the products from the products through the intermediaries to the consumers. This is made with the aim to stimulate the product's purchases from them. One of the effective manners of purchase promotion is the approach to the consumer. Thus, this refers to buyers or intermediaries through the direct marketing that has multiple benefits such as sales growth, information in time, brand recognition and product's exposition, loyalty stimulation, keeping the contacts with the partners, etc. If we observe a typical SME in Kosovo, we note that the purchase promotion of a company includes many types of promotional activities that have the aim to stimulate the immediate reaction of the market and consumer. The promotion sales instruments used are: Sales promotion customer oriented; Sales promotion intermediaries oriented; Sales promotion staff oriented. In this case, the difficulty entails the lack of a marketing department in companies. The consequence of this is the slow flow of information, and this makes it necessary to build an effective system of information in the company that will make possible faster information flow to interested parties within the company. However, this stimulates the need that within the company, marketing units must be created to carry out marketing research, gather and produce statistics, public relations and company's promotion, and different manager supports with developing the marketing activities. The marketing unit, however, must participate in planning, organizing, and implementing the promotion activities of the company. These activities are made with the aim to increase the company's sales, inform the consumer about the new products, find new consumers, or strengthen the relations with the existing consumers. This, therefore, will surely bring positive results to the company. It must be highlighted that in the daily practice of using marketing activities in favor of business advancing, the companies or majority of them use promotion methods and instruments and different elements such as product, price, and distribution policies. These remaining specific cases are inspired occasionally by the knowledge gained abroad or the inspiration of the people that are entrepreneurs with experience. This is because business growth also requires other daily interventions.

\section{Conclusions and Recommendations}

In this paper, we aimed at presenting the interconnection of legal regulation that will make SMEs develop their own business using, among other things, marketing. This is seen as an instrument that supports the growth of the business and gets competitive advantages on the market where they operate, sells, or offers the same or approximate products of services. Due to the freedom of access to the Kosovo market of foreign companies and products, the Kosovo SMEs in this phase, except the knowledge and experience in the local market, must have and gain knowledge about business trends in the world. This knowledge must be implemented in practice. The environment where the Kosovo SMEs operate is not favorable for them. At the same time, it does not protect and support the national market, and it has difficulties selling the products in foreign markets. The marketing and its use in the world has advanced, and there are big investments of the companies. In the case of SMEs based on the implementation of marketing activities, there are no any plans or great division of funds and neither investment in human resources. Finally, for SMEs, there is a possibility to use the marketing services of marketing agencies as an alternative to their marketing 
department. In this paper, we analyzed the existing legal regulation in Kosovo and the marketing activities used by SMEs in their daily businesses. It remains that in the future, to follow the development of SMEs, we should learn from the mistakes and the successes of different successful companies. Therefore, the pre-conditions are created, and the local companies can use good practices and have some of the factors as an advantage. For example, the qualified human power, the infrastructures in improvement and advancement, and the access in integration processes of EU are used to make possible the production, distribution, and competition power of SMEs within the country and abroad.

\section{References}

Barney, J. (1991). Firm Resources and Sustained Competitive Advantage. Journal of Management, Volume 17, 99-120. Retrieved from http://dx.doi.org/10.1177/014920639101700108

Davig, W., \& Brown, S. (1992). Incremental decision making in small manufacturing firms. Journal of Small Business Management, Volume 30, 53-60.

John, G., \& Arthur, T. J. (2010). Essential of strategic Management: The quest of Competitive Advantages. McGraw-Hill/Irwin.

Kosovo Agency of Statistics. (2017). Vjetari statistikor i republikes se Kosoves 2017, http:/lask.rksgov.net/media/3636/vjetari_statistikor_i_republik\%C3\%ABs_-s\%C3\%AB_-kosov\%C3\%ABs_-2017_final.pdf

Nexhbi, V. (2009). Principles of Marketing (2nd edition). Maqedoni: Alma Shkup.

Ukaj, F. (2010a). Marketing Concept as a tool for Development of Tourism in Kosovo. Journal of Environmental Management and Tourism (JEMT), Volume 1(1), 57-62.

Ukaj, F. (2010b). The role of the Management in Kosovo SMEs, The help they need to overcome the Economic Crisis. Journal of Advanced Research in Management JARM, Volume 1(2), 139-144.

Ukaj, F. (2018). The Role of Internet in Successful Marketing in Tourism Organizations. Journal of Environmental Management and Tourism JEMT, Volume 9(5). Retrieved from https://journals.aserspublishing.eu/jemt/article/view/2597. 